\title{
BoARd Gender QuOTAS In GeRmany AND THE EU: AN APPROPRIATE WAY OF EQUALISING THE PARTICIPATION OF WOMEN AND MEN?
}

\author{
RAPHAEL KOCH*
}

The professional equalisation of men and women has become one of the most discussed topics in politics over the last years. As a solution to this problem many European countries have introduced regulations which ensure special quotas for women on the managing boards of companies. The main problem concerning such gender quotas is that the equalisation of men and women is primarily a sociopolitical objective which might result in a possible conflict with national and European constitutional law. Consequently, the current legal situation in Germany and the EU needs to be analysed critically. Therefore the different ways of incorporating gender quotas into the existing legal system must be compared with each other.

\section{INTRODUCTION}

If you take a look at current developments and perspectives in company law, you will notice that companies - particularly stock corporations under German law (Aktiengesellschaften) - have been given greater responsibility for the realisation of sociopolitical goals in recent years. The overlap between the law governing stock corporations and sociopolitical thinking has become a fashionable topic. ${ }^{1}$ Both the German and the European legislators are pursuing the realisation of sociopolitical goals in this regard. Under the key words

* DrJur (University of Münster), DrJurHabil (University of Münster), LLM (University of Cambridge); Professor of Law and Chair of Civil Law, Law of Civil Procedure, Corporate and Company Law, European Private Law and International Procedural Law at University of Augsburg.

${ }^{1}$ Mathias Habersack, 'Staatliche und halbstaatliche Eingriffe in die Unternehmensführung Gutachten E', Verhandlungen des 69 Deutschen Juristentages, München, 2012, vol 1, 2012) 33. See also Holger Fleischer, 'Zukunftsfragen der Corporate Governance in Deutschland und Europa: Aufsichtsräte, Institutionelle Investoren, Proxy Advisors und Whistleblowers’ (2011) 40 Zeitschrift für Unternehmens- und Gesellschaftsrecht 155, 157. 
'corporate governance' or 'corporate social responsibility', it is widely discussed whether and to what extent sociopolitical (wishful) thinking as an aspect of good company management can and should be made the object of legislation. The fact that company law is increasingly influenced by social developments is shown by the Act on the Appropriateness of Management Board Remuneration (Gesetz zur Angemessenheit der Vorstandsvergütung ['VorstAG']), for example'2. Meanwhile, section 87 paragraph 1 of the Stock Corporation Act (Aktiengesetz ['AktG']) requires that the salaries of members of the management board be 'in reasonable proportion to the duties and services of the members of the management board', and that they be aligned with 'sustainable company development'. Even though the limitation of management board salaries is primarily a reaction to the financial crisis, it also addresses social issues at the same time. ${ }^{3}$ In recent times, this development has been particularly clear in discussions on introducing statutory quotas on the proportion of women in management positions in companies. The call for 'gender diversity' has not stopped at company law. ${ }^{4}$ The realisation of equal opportunities for the professional equality of men and women is primarily a sociopolitical goal. ${ }^{5}$ It is problematic in this respect, and therefore particularly worthy of discussion, as quotas on the number of women occupying board positions constitute a form of 'state intervention' in corporate internal conflicts. ${ }^{6}$

At first glance, the figures and statistics support the introduction of statutory quotas. A study by the German Institute for Economic Research (Deutsches Institut für Wirtschaftsforschung) found that, in 2013, the proportion of women on the management boards of the Top 200 companies was only 4.4 per cent, and the proportion on supervisory boards was 15.1 per cent. ${ }^{7}$ The reasons given

${ }^{2}$ Act of July 312009 BGBI. I 2509.

3 Thomas M J Möllers and Sabrina Hailer, 'Möglichkeiten und Grenzen staatlicher und halbstaatlicher Eingriffe in die Unternehmensführung' (2012) 67 Juristische Zeitung 841, 847. See also in full Ulrich Seibert, 'Die Koalitionsarbeitsgruppe "Managervergütungen”: Rechtspolitische Überlegungen zur Beschränkung der Vorstandsvergütung (Ende 2007 bis März 2009)', in: Festschrift für Uwe Hüffer zum 70 Geburtstag (C H Beck, 2010) 955ff and Gregor Bachmann, 'Corporate Governance nach der Finanzkrise' (2011) 56 Die Aktiengesellschaft 181, 185 with further references.

${ }^{4}$ Habersack, above n 1, 34.

${ }^{5}$ Katja Langenbucher, 'Frauenquote und Gesellschaftsrecht' (2011) 66 Juristische Zeitung 1038; Habersack, above n 1, 34.

${ }^{6}$ Walter Bayer, 'Grundsatzfragen der Regulierung der aktienrechtlichen Corporate Governance' (2013) 16 Neue Zeitschrift für Gesellschaftsrecht 1, 6.

${ }^{7}$ Elke Holst and Anja Kirsch, 'Frauen sind in Vorständen großer Unternehmen in Deutschland noch immer die Ausnahme - moderat steigende Anteile in Aufsichtsräten' (2014) 3 Deutsches Institut für Wirtschaftsforschung: Wochenbericht 20 <http://www.diw.de/ documents/publikationen/73/diw_01.c.435168.de/14-3-1.pdf>. 
for this included personality differences between men and women, as well as structural obstacles such as the compatibility of family and a career. ${ }^{8}$ The very real under-representation of women in management positions is not just a German phenomenon. It can also be seen in many other European countries, with Scandinavia having the highest quotas. ${ }^{9}$ Interestingly, it is within society that there is the greatest agreement on the necessity to introduce quotas on women, but the exact organisation of such quotas is fiercely disputed. ${ }^{10}$

This article provides an overview of current developments in Germany and the European Union. Following a brief description of the advantages and disadvantages of quotas on women in managerial roles (Part II), the status quo in Germany and the EU is addressed and current legislation is discussed (Part III). The constitutional hurdles and the hurdles in European law of implementing quotas on women are then taken into consideration (Part IV). Finally, the legal situation is critically evaluated (Part V) and the prospect of future development is examined (Part VI).

\section{AdVAntages AND Disadvantages OF QuOTAS ON WOMEN}

Advocates of quotas on women occupying management positions refer to studies in which 'gender diversity' in management positions leads to greater economic success for the company. ${ }^{11}$ The increased involvement of women on management boards is said to lead to more ideas and creativity in corporate decisions, and these decisions are said to be more closely scrutinised; potential

\footnotetext{
${ }^{8}$ See Kathrin Brandt, Gleichstellungsquote im Aufsichtsrat der Aktiengesellschaft (Peter Lang, 2012) 34ff.

9 See statistical data in Marcus Schladebach and Georgia Stefanopoulou, 'Frauenquote in Aufsichtsräten - Überlegungen zur Änderung des Aktienrechts’ (2010) 65 Betriebs-Berater 1042, 1043.

${ }^{10}$ Leonhard Knoll and Daniel Lochner, ‘Diskriminierung durch Quote?’ (2014) 67 Der Betrieb 495.

${ }^{11}$ For example, see various studies by McKinsey \& Company on the topic 'Women Matter' $<$ http://www.mckinsey.com/features/women_matter>; also the references in Ina Anne Frost and Leena Linnainmaa, 'Corporate Governance — Frauen im Aufsichtsrat — Können wir von unseren skandinavischen Nachbarn lernen?’ (2007) 52 Die Aktiengesellschaft 601, 609; HansJürgen Papier and Martin Heidebach, 'Die Einführung einer gesetzlichen Frauenquote für die Aufsichtsräte deutscher Unternehmen unter verfassungsrechtlichen Aspekten’ (2011) 40 Zeitschrift für Unternehmens- und Gesellschaftsrecht 305, 309ff; Bachmann, above n 3, 189; also Barbara Mayer, 'Vier Thesen für die Frauenquote in Aufsichtsräten' (2011) 61 Anwaltsblatt 919.
} 
economic growth is better exploited. ${ }^{12}$ Also in line with this is the argument that the negative effects of the financial crisis would not have occurred if there had been a higher proportion of women on corporate boards. ${ }^{13}$ However, too much significance should not be attributed to assumptions and investigations of this sort. Ultimately, all studies are burdened with the problem that it cannot be demonstrated whether a company would be more or less successful in the same reference period with more or fewer women in management positions. ${ }^{14}$ It is also pointed out that the qualification level of women has grown in recent years, which is why the under-representation of women on supervisory boards is no longer justifiable. ${ }^{15}$ The current situation is put down to the issue that men would rather appoint a man in case of doubt and critically compare female applications with each other ('cartel argument'). ${ }^{16}$

A clear disadvantage of quotas on women is that every quota automatically constitutes discrimination against male applicants. In other words, a quota on women would have the effect of a government ban on filling a specific portion of the supervisory board with male candidates. ${ }^{17}$ If the under-representation of women were called discrimination, the introduction of quotas on women would lead to a so-called 'reverse discrimination' against men, ${ }^{18}$ so to speak, the admissibility of which would have to be determined by constitutional benchmarks in particular. ${ }^{19}$ However, a quota regulation is associated with a

12 European Commission, Proposal for a Directive of the European Parliament and of the Council on Improving the Gender Balance among Non-Executive Directors of Companies Listed on Stock Exchanges and Related Measures (COM(2012), 14 November 2012, 614 final) ('EC Draft Directive 2012') 4.

${ }^{13}$ European Commission, Green Paper - Corporate Governance in Financial Institutions and Remuneration Policies (COM(2010), 2 June 2010, 284 final) 7, 13. Therefore, it is not surprising when statements such as 'This wouldn't have happened like that with the Lehman Sisters' appear in the media: cited in Brandt, above n 8, 15.

${ }^{14}$ Bachmann, above n 3, 189. See also Heribert Hirte, 'Frauenquote oder Frauenförderung' (2013) 11 Der Konzern 367, 371; Thüsing, 'Die Frauenquote ist europarechtswidrig', Frankfurter Allgemeine Zeitung, 10 December 2014, 16.

${ }^{15}$ Draft Act by the Federal Government for the Equal Participation of Men and Women in Management Positions in Private Industry and Public Services (Entwurf eines Gesetzes für die gleichberechtigte Teilhabe von Frauen und Männern an Führungspositionen in der Privatwirtschaft und im öffentlichen Dienst), 11 December 2014, 48 <http://www.bmjv. de/SharedDocs/Downloads/DE/pdfs/Gesetze/GE-Frauenquote.pdf;jsessionid=08C7AC077 DE5817999C517E551D8FC8C.1_cid297?_blob=publicationFile>.

${ }^{16}$ Mayer, above n 11, 919.

${ }^{17}$ Papier and Heidebach, above n 11, 314.

${ }^{18}$ This principle also exists in US law. The so-called 'affirmative actions' there are intended to achieve the equality of African Americans on the labour market in particular. See Matthias Döring, Frauenquoten und Verfassungsrecht (Duncker \& Humblot, 1996) 16ff in this regard.

${ }^{19}$ See also below Part IVA. 
certain degree of discrimination against women at the same time: a woman will no longer be employed on the grounds of her qualifications and experience but rather on the grounds of her gender - she thus becomes a 'token woman'. ${ }^{20}$ The issue of introducing quotas on women is therefore associated with the issue of the professional quality of supervisory board members. There are concerns about whether there are even enough suitably qualified women to fill supervisory boards. ${ }^{21}$ Therefore, opponents of quotas on women stress that the qualifications and quality of a potential supervisory board member must be decisive for their appointment first and foremost. ${ }^{22}$ This is another reason why company law is not considered adequate for the realisation of sociopolitical (wishful) thinking. ${ }^{23}$ Quotas on women are deemed an alarming 'foreign body in the law governing stock corporations'.24

However, the advantages and disadvantages of quotas on women still only play a minor role in the current discussion. As the political decision to increase the proportion of women on boards in Germany and the EU was made long ago, ${ }^{25}$ the only issue for discussion now is the specific organisation and implementation of a quota on women. ${ }^{26}$ The advantages and disadvantages of a quota on women should not be completely ignored, however; they may still be important stimuli for the organisation of a statutory quota.

\section{The Status Quo in Germany and the EU}

\section{A Germany}

Before statutory quotas were introduced, the legal situation in Germany was characterised by the 'principle of voluntary obligation'. ${ }^{27}$ The German

\footnotetext{
${ }^{20}$ Gerd Krieger, ‘Keine Gesetzliche Frauenquote für Aufsichtsräte’ (2011) 61 Anwaltsblatt 918; Martin Peltzer, 'Der Bericht der Corporate Governance Kommission an die Bundesregierung' (2011) 14 Neue Zeitschrift für Gesellschaftsrecht 281, 283.

${ }^{21}$ Bayer, above n 6, 8.

${ }^{22}$ Krieger, above n 20, 918.

${ }^{23}$ Peter Mülbert, 'Corporate Governance in der Krise' (2010) 174 Zeitschrift für das gesamte Handels- und Wirtschaftsrecht 375, 380, 384; Bachmann, above n 3, 189 with further references.

${ }^{24}$ Habersack, above n 1, 36.

${ }^{25}$ See also Part III below.

${ }^{26}$ Bachmann, above n 3, 189; Marc-Philippe Weller, 'Wie Quoten juristisch durchgesetzt werden können’ Frankfurter Allgemeine Zeitung, 8 June 2011, 19; Bayer, above n 6, 9.

${ }^{27}$ An overview of the development of quotas on women in recent years can also be found in Christoph Teichmann and Carolin Langes, 'Frauenquote in Deutschland und Europa' (2013) 24 Europäisches Wirtschafts- und Steuerrecht 175f; Stefanie Jung, 'Eine Frauenquote für die
} 
Corporate Governance Code ('GCGC') (Deutscher Corporate Governance Kodex $),{ }^{28}$ does indeed state with regard to the appointment of the supervisory board that specific targets should be set for the board's composition, and that these targets should specify an 'adequate proportion of women' in particular (GCGC [5.4.1]). ${ }^{29}$ The legal nature of the provisions of the GCGC means that they are only recommendations, however, and are not legal obligations for companies. In this respect, this can be considered a soft law approach. ${ }^{30} \mathrm{In}$ accordance with the so-called 'comply or explain' principle, companies can also deviate from the recommendations provided that they disclose and justify this. ${ }^{31}$

\section{Legislative Process}

In their coalition treaty in 2013, the current German government comprising the Christian Democratic Union (Christlich Demokratische Union ['CDU']), the Christian Social Union (Christlich Soziale Union ['CSU']) and the Social Democratic Party of Germany (Sozialdemokratische Partei Deutschlands ['SPD']) stated their wish to increase the proportion of women on company boards. ${ }^{32}$ There had been previous attempts to introduce a quota on women. ${ }^{33}$ However, these plans were not implemented in previous parliamentary terms. In March 2014, the German Federal Ministries of Justice and Family Affairs (Bundesministerien für Justiz und Familien) published initial guidelines for the legislative procedure, ${ }^{34}$ which revisited the agreements in the coalition

EU?' (2013) 68 Betriebs-Berater 387, 388; Schladebach and Stefanopoulou, above n 9, 10434; extensively Brandt, above n 8, 41ff.

28 The latest version of the GCGC (as at 5 May 2015) is available at $<$ http://www.dcgk.de/de/kodex.html>.

${ }^{29}$ Similar recommendations can commonly be found on appointments to management positions (GCGC [4.1.5]) and on the composition of the management board (GCGC [5.1.2]).

${ }^{30}$ Teichmann and Langes, above n 27, 179.

${ }^{31}$ Preamble to the GCGC.

${ }^{32}$ Shaping Germany's Future. Coalition Treaty between CDU/CSU and SPD (Deutschlands Zukunft gestalten. Koalitionsvertrag zwischen CDU, CSU und SPD) 2013, 72 $<$ https://www.cdu.de/sites/default/files/media/dokumente/koalitionsvertrag.pdf>. In 2012 there were two legislative initiatives by the Federal Council and the SPD fraction; see Teichmann and Langes, above n 27, 176.

33 In particular, see the legislative proposals by Alliance 90/The Greens from 2007 (BTDrucksache 16/5279 <http://dip21.bundestag.de/dip21/btd/16/052/1605279.pdf> [Parliamentary Documentation of the German Bundestag]) and 2009 (BT-Drucksache 16/12108 <http://dip21.bundestag.de/dip21/btd/16/121/1612108.pdf> [Parliamentary Documentation of the German Bundestag]).

${ }^{34}$ Act for the Equal Participation of Men and Women in Management Positions in Private Industry and Public Services. Guidelines for the Legislative Procedure, 24 March 2013 $<$ http://www.bmfsfj.de/BMFSFJ/gleichstellung,did=205630.html>. 
agreement. A common draft bill was finally presented by both ministries in June 2014, ${ }^{35}$ which was amended in September 2014 (new version). ${ }^{36}$ The Federal Minister of Justice (Heiko Maas) expressly justified the procedure by stating that previous attempts at voluntary obligation had brought no success. ${ }^{37}$ Over the next months the legislative process was delayed as - despite the coalition treaty - concerns were raised by parts of the coalition. Members of the CDU and CSU criticised the inflexibility of the draft bill, especially as there were no exemptions ('hardship clauses') from the quota regulation. ${ }^{38}$ Nevertheless, the leaders of the ruling parties were able to reach a final agreement on the draft bill, ${ }^{39}$ which was approved by the German federal government on 11 December 2014. ${ }^{40}$ In March 2015 both chambers (Bundestag ${ }^{41}$ and Bundesrat ${ }^{42}$ ) of the German parliament finally passed the Law for the Equal Participation of Men and Women in Management Positions in Private Industry and Public Services (Gesetz für die gleichberechtigte Teilhabe von Frauen und Männern an Führungspositionen in der Privatwirtschaft und im öffentlichen Dienst).$^{43}$ The introduction of a statutory quota on women is intended to increase the proportion of women in

\footnotetext{
${ }^{35}$ Draft Act for the Equal Participation of Men and Women in Management Positions in Private Industry and Public Services, 20 June 2014 <http://www.arbrb.de/media/ Referentenentwurf_Geschlechterquote.pdf $>$.

${ }^{36}$ Joachim Jahn, 'Gesetz für Frauenquote wird entschärft', Frankfurter Allgemeine Zeitung, 10 September 2014, 16.

37 'Voluntarily, it won't work. The mandatory quota is coming; there will be no exceptions. The time of fruitless lip service is over' ('Freiwillig funktioniert es nicht. Die verbindliche Quote kommt, da wird es keine Ausnahmen geben. Die Zeit der fruchtlosen Lippenbekenntnisse ist vorbei': Press Release by the Federal Ministry of Justice and Consumer Protection, (Gemeinsamer Referentenentwurf zur Frauenquote vorgestellt) 22 June 2014 <http://www.bmjv.de/SharedDocs/Interviews/DE/2014/Print/20140622_BZ_Frauenquote.htm l?nn=343322>.

${ }^{38}$ Constanze von Bullion, 'Warten auf ein Machtwort der Kanzlerin', Süddeutsche Zeitung, 24 November 2014, 4.

39 'Koalitionsausschuss: Schwarz-rot einigt sich auf Frauenquote', Die Zeit (online), 26 November 2014 <http://www.zeit.de/politik/deutschland/2014-11/frauenquote-einigungkoalition>.

40 'Förderung von Frauen in Führungspositionen: Kabinett beschließt Gesetzentwurf zur Frauenquote', Federal Ministry of Justice and Consumer Protection, 11 December 2014, <http://www.bmjv.de/SharedDocs/Kurzmeldungen/DE/2014/20141211-Frauenquote.html?nn $=3433226>$.

41 'Mehr Frauen in Führungspositionen - Bundestag beschließt Gesetz zur Frauenquote', Federal Ministry of Justice and Consumer Protection, 6 March 2015, <http://www.bmjv.de/SharedDocs/Pressemitteilungen/DE/2015/20150306-Frauenquote.html ?nn=1468684>.

${ }^{42}$ Ibid.

${ }^{43}$ Act of April 242015 BGBl. I 642.
} 
management positions. Another declared objective of the new law is the reduction of the wage gap between men and women. ${ }^{44}$

\section{Content of the New Law}

The gender quota is directly embedded into company law. In companies that are listed on the stock market and subject to co-determination, from 2016 at least 30 per cent of the supervisory board must be women, and at least 30 per cent must be men. The gender quota applies for both shareholders' representatives and employees' representatives. ${ }^{45}$ The number of companies affected by this is estimated to be approximately $108 .^{46}$ If the gender quota is not complied with, the election of the supervisory board shall be invalid ${ }^{47}$ so that the supervisory board posts provided for women remain free (so-called empty seats). ${ }^{48}$

For companies that are either listed on the stock market or subject to codetermination, a so-called 'flexi-quota' applies from 30 September 2015. ${ }^{49}$ About 3500 companies will be affected by this rule. ${ }^{50}$ Under this rule, the supervisory board has to set target figures for increasing the proportion of women both on the supervisory board and the executive board ${ }^{51}$ Consequently, there is no obligation to achieve a special quota. ${ }^{52}$ If the proportion of women was below 30 per cent when the targets were set, companies are not permitted to fall below this status quo. ${ }^{53}$ In contrast to the strict 30 per cent quota there are no sanctions when the flexi-quota is not complied with. The 'comply or

${ }^{44}$ Draft Act by the Federal Government for the Equal Participation of Men and Women in Management Positions in Private Industry and Public Services, above n 15, 49.

${ }^{45}$ Aktiengesetz [AktG] § 96 para 2.

46 Draft Act by the Federal Government for the Equal Participation of Men and Women in Management Positions in Private Industry and Public Services, above n 15, 51.

${ }^{47}$ AktG $§ 250$ para 1 no 5.

48 Draft Act by the Federal Government for the Equal Participation of Men and Women in Management Positions in Private Industry and Public Services, above n 15, 52.

49 Einführungsgesetz zum Aktiengesetz [EGAktG] § 25 para 1. Such a model was previously proposed by the former Federal Minister of Family Affairs Kristina Schröder. According to it the proportion of women should be determined independently and reported publicly. See Teichmann and Langes, above n 27, 176.

50 Draft Act by the Federal Government for the Equal Participation of Men and Women in Management Positions in Private Industry and Public Services, above n 15, 54.

${ }^{51}$ AktG $\S 111$ para 5.

52 Ingrid Ohmann-Sauer and Moritz Langemann, 'Der Referentenentwurf zur Einführung einer “gesetzlichen Frauenquote’ (2014) 31 Neue Zeitschrift für Arbeitsrecht 1120, 1125.

${ }^{53}$ AktG $\S 111$ para 5. 
explain' principle from the GCGC still applies, however. ${ }^{54}$ Originally the draft bill from June 2014 stated that the self-determined target figures must require the appointment of at least one man and one woman (so-called effective appointment). ${ }^{55}$ This was intended to prevent solely men or women being appointed to supervisory boards. ${ }^{56}$ However, according to data from the Federation of German Industries (Bundesverband der Deutschen Industrie), the supervisory boards of approximately 60 per cent of these companies consist of only three people. ${ }^{57}$ Therefore, via a loophole, a rigid 33 per cent quota for both genders would have been introduced for a number of companies. Consequently, the new version of the draft bill of 9 September $2014^{58}$ already no longer featured the wording 'the target figures must require the appointment of at least one man and one woman'.

The same is true for other managing positions. The executive board must also set target figures for increasing the proportion of women in positions below the supervisory and the executive board. ${ }^{59}$ The goal of this regulation is to promote women at all operational levels. ${ }^{60}$

Companies in the legal form of a European Company (Societas Europaea ['SE']) also fall under the quota regulation. ${ }^{61} \mathrm{~A}$ stock listed SE whose

\footnotetext{
${ }^{54}$ Handelsgesetzbuch $[H G B] \S 289 a$ para 2; see Ohmann-Sauer and Langemann, above n 52, 1125.

${ }^{55} A k t G-E \S 111$ para 5 as in the version of the Draft Act by the Federal Government for the Equal Participation of Men and Women in Management Positions in Private Industry and Public Services, 20 June 2014, above n 35.

${ }^{56}$ Draft Act by the Federal Government for the Equal Participation of Men and Women in Management Positions in Private Industry and Public Services, above n 35, 102.

57 Joachim Jahn, 'Frauenquote trifft viel mehr Firmen als angekündigt', Frankfurter Allgemeine Zeitung (online), 24 June $2014<$ http://www.faz.net/aktuell/wirtschaft/wirtschaftspolitik/ gesetzentwurf-der-spd-frauenquote-trifft-viel-mehr-firmen-als-angekuendigt-13008330. html>.

${ }^{58}$ See Joachim Jahn, 'Gesetz für Frauenquote wird entschärft', above n 36, 16.

${ }^{59}$ AktG § 76 para 4.

${ }^{60}$ Draft Act by the Federal Government for the Equal Participation of Men and Women in Management Positions in Private Industry and Public Services, above n 15, 145-6; see also Gregor Thüsing, 'Gerechtigkeit à la européenne: Diskriminierungsschutz in einer pluralistischen Gesellschaft' (2014) 13 Zeitschrift für europäisches Sozial- und Arbeitsrecht 364, 371.

${ }^{61}$ Draft Act by the Federal Government for the Equal Participation of Men and Women in Management Positions in Private Industry and Public Services, above n 15, 51-2, 165-6.
} 
supervising board consists of the same number of representatives of both the shareholders and the employees must fulfil the 30 per cent quota. ${ }^{62}$

\section{B European Union}

In November 2012, the European Commission issued a proposal for a directive to guarantee the balanced representation of men and women in leading corporate positions (hereinafter referred to as the Draft Quota on Women Directive). ${ }^{63}$ According to this, the proportion of women in the positions of non-executive directors and supervisory board members should be 40 per cent by $2020 .{ }^{64}$ On the other hand, a fixed quota is not specified for executive directors and board members. This is solely intended to ensure the balanced representation of both genders in EU member states. ${ }^{65}$ This compromise should avoid too much interference in the company structure. ${ }^{66}$ Only listed companies would fall within the scope of application of the Directive; small and mediumsized companies would be exempt. ${ }^{67}$ According to EU data, approximately 5000 companies would be affected by the Directive. ${ }^{68}$ The affected companies would have to report to the member states on an annual basis with regard to whether the targets had been reached. ${ }^{69}$ In this respect, the proposed Directive would impose a mixture of a fixed quota on the one hand and a voluntary obligation on the other. Breaches of the targets would be subject to sanctions. Member states would be responsible for implementing the targets, which could impose sanctions such as penalties, the invalidity of appointments to a supervisory board, and declarations of invalidity by a court. ${ }^{70}$

\footnotetext{
${ }^{62}$ Gesetz zur Ausführung der Verordnung (EG) Nr. 2157/2001 des Rates vom 8. Oktober 2001 über das Statut der Europäischen Gesellschaft (SE) [SEAG] § 17 para 2; see also SEAG § 24 para 3.

${ }^{63}$ EC Draft Directive 2012, above n 12. With regard to previous EU measures see Jung, above $n$ 27, 387f. The question of whether article 157 para 3 TFEU is a suitable legal basis is strongly disputed. See also Jens Koch, 'EU-Kompetenz für eine Frauenquote in den Führungsgremien von Aktiengesellschaften' (2011) 175 Zeitschrift für das gesamte Handels- und Wirtschaftsrecht 827ff; Knoll and Lochner, above n 10, 497 with further references; Teichmann and Langes, above n 27, 181 with further references.

${ }^{64}$ EC Draft Directive 2012, above n 12, art 4(1).

65 Ibid art 5(1).

${ }^{66}$ Ibid art 6.

${ }^{67}$ Ibid art 1, 3.

68 Jung, above n 27, 389.

${ }^{69}$ EC Draft Directive 2012, above n 12, art 5(2).

${ }^{70}$ Ibid art 6(2) a) and b).
} 
The legislative procedure for adopting this Directive is not yet complete. In November 2013, the European Parliament approved the Commission's proposal for a directive. However, the adoption of the Directive still requires the approval of the Council (also referred to as the EU Council of Ministers). ${ }^{71}$ In July 2013, nine member states — including Germany — reaffirmed in a joint declaration that they do not agree with the proposal for a directive. This achieved a blocking minority, which could prevent the adoption of the planned Directive. ${ }^{72}$ Given the current legislative plans of the German federal government, Germany could change its position again. In particular, the former EU Justice Commissioner, Viviane Reding, has expressed the hope that the German government will relent. Germany's own plans could mean that it becomes a pioneer in the issue of quotas on women within the EU. ${ }^{73}$

\section{Other European Countries}

There are also quota regulations in other European countries. ${ }^{74}$ It is primarily the Scandinavian countries that are role models, particularly Norway. A statutory quota requiring 40 per cent of the members of company management boards to be women was introduced there in 2003. ${ }^{75}$ A 40 per cent quota on women was passed in Spain in 2007; this must be implemented by the affected companies by $2015 .{ }^{76}$ France adopted a law on the equality of men and women on management and supervisory boards and on professional equality in $2011 .{ }^{77}$ According to this law, both genders must be represented on the management and supervisory boards of large companies at a rate of at least 40 per cent from

\footnotetext{
${ }^{71}$ With regard to the legislative procedure in the EU, particularly on the correct legislative procedure in accordance with art 289 para 1, 294 TFEU [Treaty on the Functioning of the European Union], see Rudolf Streinz, Europarecht (C F Müller, $9^{\text {th }}$ ed, 2012) $198 \mathrm{ff}$.

72 Florian Eder, 'Frauenquote in der EU steht vor dem Aus', Die Welt (online), 26 July 2013 $<$ http://www.welt.de/wirtschaft/article118412204/Frauenquote-in-der-EU-steht-vor-demAus.html $>$. With regard to the change in requirements for a qualified majority, which apply from 1 November 2014, see Streinz, above n 71, 122.

73 'EU-Parlament stimmt für Frauenquote in Aufsichtsräten', Die Zeit (online), 20 November $2013<$ http://www.zeit.de/karriere/2013-11/eu-parlament-frauenquote>.

${ }^{74}$ See the overview in Teichmann and Langes, above n 27, 177-8 in this regard and the extensive coverage in Brandt, above n 8, 48ff with remarks on Norway, Spain and France.

75 Teichmann and Langes, above n 27, 177. See also Frost and Linnainmaa, above n 11, $603 \mathrm{ff}$.

${ }^{76}$ Teichmann and Langes, above n 27, 180; Brandt, above n 8, $52 f$.

${ }^{77}$ Loi relative à la représentation équilibrée des femmes et des hommes au sein des conseils d'administration et de surveillance et à l'égalité professionnelle, 28 January 2011 $<$ http://www.legifrance.gouv.fr/affichTexte.do?cidTexte=JORFTEXT000023487662\&dateTe xte $=\&$ categorieLien $=i d>$. See also Raphaële François-Poncet, Barbara Deilmann and Sabine Otte, 'Frauenquote in französischen Aufsichts- und Verwaltungsräten — ist eine Quote auch in Deutschland zulässig?’ (2011) 14 Neue Zeitschrift für Gesellschaftsrecht 450, 451ff.
} 
2017. ${ }^{78}$ In the same year, the Netherlands passed a statutory quota of 30 per cent female membership of the management and supervisory boards of stock corporations. ${ }^{79}$ There is also a 33 per cent quota for both genders in Italy. ${ }^{80}$

A statutory quota on women of at least 35 per cent by 2018 was introduced in Austria in 2011. However, this applies only to quasi-public companies companies in which the state holds at least a 50 per cent interest. ${ }^{81}$ There is a similar regulation in Finland, which imposes a statutory quota of 40 per cent for public companies and companies that are majority-owned by the state. ${ }^{82}$

On the other hand, there are still countries — especially Sweden — where no statutory quotas have been introduced yet. ${ }^{83}$ The Swedish Corporate Governance Code, like its German counterpart, only requires companies to endeavour to achieve an equal distribution of both genders. ${ }^{84}$ Finally, there are similar regulations in Denmark, where the principle of voluntary obligation also prevails. This is particularly apparent from the recent amendment of a law, according to which companies must set their own quota for the underrepresented gender and report this publicly. ${ }^{85}$

\section{Interim Findings}

The introduction of quotas on women has been highly topical in European countries in recent years, which is why there is real talk of a 'race'. ${ }^{86}$ Quotas on women are on the agenda! Of course, individual regulations differ from each other in the degree of female participation that they require, with a quota of 40 per cent currently being the highest. ${ }^{87}$ The individual regulations can also be assigned to three categories: those in which quotas are targeted only at

\footnotetext{
${ }^{78}$ François-Poncet et al, above n 77, 452.

79 Tineke Lambooy, '30\% Women on Boards: New Law in the Netherlands (2012)' (2012) 9

European Company Law $53 f f$ gives extensive coverage on this issue.

${ }^{80}$ Teichmann and Langes, above n 27, 181.

81 See Frauen in Spitzenpositionen. Modelle in Osterreich, Bundeskanzleramt Osterreich $<$ http://www.bka.gv.at/site/6868/default.aspx>.

82 Act on Equal Status and Equal Rights of Women and Men, No 10/2008 $<$ http://eng.velferdarraduneyti.is/media/acrobat-enskar_sidur/Act-on-equal-status-and-equalrights-of-women-and-men_no-10-2008.pdf>.

${ }^{83}$ Teichmann and Langes, above n 27, 179.

${ }^{84}$ Swedish Corporate Governance Code ('SCGC') [III.4.1] <http://www.corporategovernance board.se/media/45322/svenskkodbolagsstyrn_2010_eng_korrigerad20110321.pdf>.

85 See in full Teichmann and Langes, above n 27, 179.

${ }^{86}$ François-Poncet et al, above n 77, 450.

${ }^{87}$ Teichmann and Langes, above n 27, 183.
} 
companies with a certain minimum size; those in which quotas apply only to majority-owned public companies; and, the third category that does not stipulate a quota but rather sets out for companies a voluntary obligation by way of a soft law.

As evidenced by the current legal situation, the German legislator has taken the middle path. There is a fixed quota of 30 per cent for large companies on the one hand, and a flexi-quota for another 3500 companies on the other hand.

\section{Legal Challenges of Introducing a QuOta on WOMEN}

\section{A Challenges of German Constitutional Law}

In Germany, the constitutionality of a statutory quota on women is disputed, ${ }^{88}$ and must be determined under articles 3, 9, 12 and 14 of the Basic Law for the Federal Republic of Germany (Grundgesetz [ ' $G G$ '] ). ${ }^{89}$ A possible breach of the general principle of equal treatment (article 3 paragraph $3 G G$ ) is of particular interest here. $^{90}$

Article 3 paragraph 3 GG prohibits, amongst other things, discrimination on the grounds of gender. The introduction of quotas on women discriminates against men and is therefore an encroachment requiring justification. ${ }^{91}$ Justification may be founded on article 3 paragraph 2 clause $2 G G$ which states: 'The state shall promote the actual implementation of equal rights for women and men and take steps to eliminate disadvantages that now exist. ${ }^{92}$ Intervention is

\footnotetext{
${ }^{88}$ Schladebach and Stefanopoulou, above n 9, 1046 argue the constitutional non-conformity of quotas on women; also Julia Redenius-Hövermann, 'Zur Frauenquote im Aufsichtsrat' (2010) 31 Zeitschrift für Wirtschaftsrecht 660, 665-6. However, the constitutionality of quotas on women is affirmed by, amongst others, Joachim Wieland, 'Ist eine Quotenregelung zur Erhöhung des Anteils der Frauen in Aufsichtsräten mit dem Grundgesetz und Europarecht vereinbar?' (2010) 63 Neue Juristische Woche 2408, 2409; Heide M Pfarr, 'Die Frauenquote' (1995) 12 Neue Zeitschrift für Arbeitsrecht 809, 812; Frost and Linnainmaa, above n 11, 610; Papier and Heidebach, above n 11, 313ff., 333; Gregor Bachmann, 'Zur Umsetzung einer Frauenquote im Aufsichtsrat' (2011) 32 Zeitschrift für Wirtschaftsrecht 1131, 1139: 'nicht per se verfassungswidrig' ['not unconstitutional per se'].

${ }^{89}$ Langenbucher, above n 5, 1039.

${ }^{90}$ Papier and Heidebach, above n 11, 313.

${ }^{91}$ Ibid 314.

${ }^{92}$ From a doctrinal point of view art 3 para 2 clause $2 G G$ is not a basic law but a state objective. Thus the individual cannot derive subjective rights from the provision. See Sonja Rademacher, Diskriminierungsverbot und ‘Gleichstellungsauftrag’ (Peter Lang, 2004) 91ff; Fritz Ossenbühl,
} 
generally justified if it is for a legitimate purpose and is suitable, necessary and proportionate. The legitimacy of quotas on women arises from the federal government's task of gender equality laid down in article 3 paragraph 2 clause $2 G G .^{93}$ Quotas are appropriate for increasing the proportion of women on supervisory boards. ${ }^{94}$ This argument arouses some scepticism because there are not enough suitably qualified women to fill the empty posts. ${ }^{95}$ It is correct to assume that intervention is appropriate, however, as the 'abstract possibility of achieving the goal' (here: increasing the proportion of women) is sufficient in this respect. ${ }^{96}$ The necessity for quotas can be affirmed as previous measures have not led to a significant increase in the proportion of women on boards. ${ }^{97}$ By contrast, the proportionality of the intervention cannot be affirmed. In the literature on constitutional law, the overriding view is that only so-called performance-related quotas are covered by the task of gender equality expressed in article 3 paragraph 2 clause 2 GG. Strict quotas are not permitted, however. ${ }^{98}$ The rule is not intended just to enable a gender quota per se. ${ }^{99}$ In the case of performance-related quotas candidates of the under-represented gender are preferred only if they are equally qualified. ${ }^{100}$ Therefore, equal professional opportunities always require equal professional qualifications. ${ }^{101}$ The European

'Frauenquoten für Leitungsorgane von Privatunternehmen' (2012) 65 Neue Juristische Woche 417, 418 with further references.

${ }^{93}$ Papier and Heidebach, above n 11, 314.

${ }^{94}$ Ibid 315.

${ }^{95}$ Redenius-Hövermann, above n 88, 665; Schladebach and Stefanopoulou, above n 9, 1046; Hirte, above n 14, 376f.

${ }^{96}$ Decisions of the German Federal Constitutional Court - Official Compilation ['BVerfGE'] 67 (1985) 157, 175 and (1985) 38 Neue Juristische Woche 121, 123; Gerald Spindler and Kathrin Brandt, 'Verfassungsrechtliche Zulässigkeit einer Gleichstellungsquote im Aufsichtsrat der börsennotierten AG’ (2011) 14 Neue Zeitschrift für Gesellschaftsrecht 401, 403.

${ }^{97}$ Papier and Heidebach, above n 11, 315; Knoll and Lochner, above n 10, 497.

${ }^{98}$ Decisions of the Federal Labor Court - Official Compilation ['BAGE'] 104 (2004) 264, 26970; Lerke Osterloh in Michael Sachs (ed), Grundgesetz: Kommentar (C H Beck, $6^{\text {th }}$ ed, 2011) [Basic Law for the Federal Republic of Germany: Commentary], art 3 GG no 287; Werner Heun in: Horst Dreier (ed), Grundgesetz Kommentar (Mohr Siebeck, $2^{\text {nd }}$ ed, 2004) [Commentary on the Basic Law for the Federal Republic of Germany] art 3 GG no 112 with further references; Schladebach and Stefanopoulou, above n 9, 1046; Redenius-Hövermann, above n 88, 665; François-Poncet et al, above n 77, 454; Thüsing, above n 60, 372; for extensive information on current opinion see Rademacher, above n 92, 211ff.

${ }^{99}$ Papier and Heidebach, above n 11, 318; Spindler and Brandt, above n 96, 402.

${ }^{100}$ Papier and Heidebach, above n 11, 316.

${ }^{101}$ Osterloh, in Sachs, above n 98, art 3 GG no 287. A different view is held by Brandt, above n 8,185 , according to which the requirement of equal qualification can never actually be achieved. Instead there would be the risk of this even being used as a reason not to appoint a woman, because the requirements of a performance-related quota would not be fulfilled even if there were only the smallest differences in qualifications. 
Court of Justice reached the same conclusion in 2000, when it addressed the compatibility of the Equal Rights Act of Hesse (Hessisches Gleichberechtigungsgesetz) with European law. ${ }^{102}$ The fixed gender quota, which will apply from 2016 for listed companies and companies subject to codetermination does not fulfil this requirement. It is a strict (as opposed to performance-related) quota, which - according to the prevailing opinion in the literature - does not comply with article 3 paragraph 3 GG. The current legal situation must be classed as unconstitutional in this respect.

Intervention in the company's freedom of economic activity - and thus occupational freedom (protected under article 12 paragraph $1 G G$ in conjunction with article 19 paragraph $3 G G$ ) - is also present. ${ }^{103}$ However, this intervention is justified. A quota on women is a so-called professiongoverning regulation, which can be justified by reasonable considerations of general welfare (here the equality of men and women in the sense of article 3 paragraph 2 clause $2 G G){ }^{104}$

Additionally, quotas on women encroach on shareholders' ownership rights, as share ownership is covered by the legal constitutional protection of article 14 paragraph 1 GG. ${ }^{105}$ Such encroachment can be justified (as shown in particular by the judgment by the German Federal Constitutional Court (Bundesverfassungsgericht) on the Co-Determination Act (Mitbestimmungsgesetz ['MitbestG'])). ${ }^{106}$ This law states, in article 7 para 1 MitBest $G$, half of the supervisory board is to be made up of shareholders'

102 European Court of Justice [EJC] — C-158/97 (2000) 53 Neue Juristische Woche 1549, 1551 (no 23). However, it is questionable and disputed whether this jurisdiction - as in the case of the supervisory board — can be transferred to appointments to committees. See also Bachmann, above n 88, 1135; Thüsing, above n 60, 372.

103 BVerfGE 50 (1979) 290, 361-2; Papier and Heidebach, above n 11, 328. If, however, one focuses on the professional freedom of the candidate concerned, the protective scope of art 12 para 1 GG cannot be considered open. As $\S 113$ AktG does not make remuneration for supervisory board members compulsory, it is already doubtful whether a supervisory board mandate is an activity focused on earnings, established for the long-term, and serving to provide and maintain a livelihood: Schladebach and Stefanopoulou, above n 9, 1046.

104 Brandt, above n 8, 129; Papier and Heidebach, above n 11, 328; Spindler and Brandt, above n 96, 404.

105 BVerfGE 50 (1979) 290, 341; Papier and Heidebach, above n 11, 323; Knoll and Lochner, above $\mathrm{n} 10$, 496. Based on all information, however, the scope of application of art 14 para 1 $G G$ will not be affected. A quota regulation would only encroach on the shareholders' future opportunities, but not on the result of commercial activity; therefore only art 12 para 1 GG is affected; Döring, above n 18, 225 with further references.

106 Gesetz über die Mitbestimmung der Arbeitnehmer (Germany) [Act on Employee CoDetermination] ('Mitbestimmungsgesetz' - 'MitbestG') of 4 May 1976 BGBl. I 1153. On the transfer of the jurisdiction of the Federal Constitutional Court see Brandt, above n 8, 149ff. 
representatives and half of employees' representatives. If a restriction of shareholder rights of this nature withstands constitutional concerns, ${ }^{107}$ then surely a quota on women would do likewise. The shareholders' election decision is not revoked by such a quota but rather is modified in so far as it is limited to persons of the under-represented gender (here: women). Such intervention is a little less severe than article 7 paragraph 1 Mitbest $G$, where the shareholders' election decision for half of the supervisory board posts is completely revoked. ${ }^{108}$ Intervention in the freedom of association would also be justified for the same reasons (article 9 paragraph $1 G G$ ). ${ }^{109}$

\section{B Compatibility with European law}

At the European level, the question of whether quotas on women are compatible with primary and secondary European law is posed. ${ }^{110}$ Quotas on women represent no breach of the fundamental freedoms of the European Single Market - particularly the freedoms of establishment (article 49 of the Treaty on the Functioning of the European Union (TFEU)) and movement of capital (TFEU article 63). ${ }^{111}$ On the one hand, the quota on women has an equal effect on residents and foreigners when founding a company; on the other hand, even when the head office of a company is relocated to Germany, the 'incorporation theory' applies, ${ }^{112}$ which is why the law of the company's state of incorporation continues to remain decisive. ${ }^{113}$ Quotas cause no breach of secondary Union law either. The Equal Treatment Directive would be taken into consideration here if necessary. ${ }^{114}$ Its scope of application is not open, however, as a

\footnotetext{
107 BVerfGE 50 (1979) 290, 343ff.

${ }^{108}$ Rademacher, above n 92, 169; Wieland, above n 88, 2409; Papier and Heidebach, above n 11, 324ff; Möllers and Hailer, above n 3, 844; Teichmann and Langes, above n 27, 177. Therefore, the quota on women should not lead to a 'change in the structure or substance of share ownership': Frost and Linnainmaa, above n 11, 610.

${ }^{109}$ See also Papier and Heidebach, above n 11, 3279ff.

110 With regard to the distinction between primary and secondary Union law see Streinz, above n 71, 1-2.

${ }^{111}$ Brandt, above n 8, 246ff; Papier and Heidebach, above n 11, 329-30; but cf Schladebach and Stefanopoulou, above n 9, 1045.

${ }^{112}$ European Court of Justice [ECJ] - C-167/01 [Inspire Art] (2003) 56 Neue Juristische Woche 3331, 3333-4.

113 Papier and Heidebach, above n 11, 329ff.

${ }^{114}$ Directive 2006/54/EC of the European Parliament and Council of July 52006 of 5 July 2006 on the Implementation of the Principle of Equal Opportunities and Equal Treatment of Men and Women in Matters of Employment and Occupation, OJ L 204/23 ('Equal Treatment Directive').
} 
supervisory board mandate does not fall under 'access to employment including vocational training and promotion'. ${ }^{115}$

A breach of the Charter of Fundamental Rights of the European Union (CFR), particularly articles 15 and 16 CFR (freedom of occupation and freedom to conduct a business), article 17 CFR (right to property), and article 23 CFR (equality between men and women), is therefore ruled out. The principle applies that the European fundamental rights are interpreted in line with the constitutional traditions of the member states (CFR article 52 paragraph 4), so that no differences from German constitutional law arise. ${ }^{116}$

\section{Evaluation of the Current Legal Situation}

The legal situation in Germany must be critically evaluated. The issue of lack of compatibility with German constitutional law is particularly problematic. It would not be surprising if the German Federal Constitutional Court had soon to make a decision on the constitutionality of a quota on women. It would be a severe setback if the quota did not withstand a judicial review — not just for the 'quota on women project' but also for the advancement of women in general. $^{117}$

Besides the issue of constitutionality, however, there are also content-related problems related to introducing gender quotas for boards of company management. Ultimately, with such a huge change to company law, the systemic coherence of the quota on women would have to be scrutinised. ${ }^{118}$ The strict quota regulation of 30 per cent has the disadvantage that companies are forced to keep a specific number of positions free for women. If one assumes that, for a short period of time some industries will have too few qualified and experienced women who are prepared to take on a supervisory board role, the quota regulation would have at least to include a hardship clause ${ }^{119}$ — as preferred by the CDU and CSU.

However, the fact that a flexi-quota has been introduced for a number of companies must be welcomed. This means that some companies still have some leeway. First, this has the advantage of allowing the companies themselves,

\footnotetext{
${ }^{115}$ Equal Treatment Directive, above n 114, art 1(a). Schladebach and Stefanopoulou, above n 9, 1045; Brandt, above n 8, 249ff; but cf Papier and Heidebach, above n 11, 331.

116 See also Brandt, above $\mathrm{n} 8,236 \mathrm{ff}$.

${ }^{117}$ François-Poncet et al, above n 77, 454.

${ }^{118}$ Weller, above n 26, 19.

${ }^{119}$ Spindler and Brandt, above n 96, 404.
} 
which are most able to do so, to assess how many women qualified for the supervisory board are currently available in the particular company. Additionally, a flexi-quota, as opposed to a strict quota, better fits into the basic principles of German private law, particularly into the principle of private autonomy. ${ }^{120}$ With flexi-quotas, the recommendations of the German Corporate Governance Code can also be continued, as additional binding provisions apply besides the target provisions of the GCGC. The extension of the GCGC's recommendations would not have been expedient. ${ }^{121}$ Embedding the quota on women into the law governing stock corporations is the next logical step. ${ }^{122}$ The stipulation that the target figures must include at least one woman and one man would certainly have had to be rejected, because - as already demonstrated - this would have introduced a strict quota regulation for over 60 per cent of the affected companies. For a number of companies, there would not have been much left of the advantages of flexible organisation. The amendment of the draft bill on 9 September 2014 achieved a mitigation of the original plans which must be considered positive.

It is also to be welcomed that, in the event of a company's failure to observe the legal provisions, an appropriate sanction is associated with the invalidity of the election of the affected supervisory board member. A quota on women without sanctions would hardly improve the legal situation, as the GCGC's recommendations are already in place. ${ }^{123}$ Instead of invalidity, contestability could also have been laid down as a sanction. ${ }^{124}$ The choice of one option or the other ultimately depends on how strongly one wishes to impose sanctions for violations. Draconian penalties, ${ }^{125}$ such as the compulsory dissolution of the company imposed by Norwegian law, would have been wholly unsuitable, however. ${ }^{126}$ Fines should also be rejected, ${ }^{127}$ at least where they are the only type of sanction. Should fines be accepted, companies would in a sense be able to 'pay a ransom' to avoid the legal provisions. Finally, it must also be welcomed that there are no sanctions in case of a violation of the flexi-quota. The lack of sanctions corresponds to the fact that the flexi-quota is a target set by the company itself. Furthermore, the duty to disclose information on whether

\footnotetext{
${ }^{120}$ Weller, above n 26, 19; see also Krieger, above n 20, 918.

${ }^{121}$ Thus justifiably Bayer, above n 6, 9; but cf François-Poncet et al, above n 77, 454.

${ }^{122}$ Also Bachmann, above n 88, 1136.

${ }^{123}$ Bayer, above n 6, 9.

${ }^{124}$ Invalidity is preferred by Bachmann, above $\mathrm{n} 88,1138$; on the other hand, contestability is argued by Langenbucher, above n 5, 1045-6; Weller, above n 26, 19.

${ }^{125}$ Bachmann, above n 88, 1138.

${ }^{126}$ Teichmann and Langes, above n 27, 178.

${ }^{127}$ For example, Italian law stipulates that fines of up to €1m can be enforced: Teichmann and Langes, above n 27, 181.
} 
the targets were reached or not (comply or explain) already exerts pressure on the particular company. ${ }^{128}$

There are also outstanding issues concerning the European perspective. In view of the variety of regulations on the Continent, the European Union's draft bill must be critically evaluated against the principle of subsidiarity. ${ }^{129}$ In accordance with article 5 paragraph 3 of the Treaty of the European Union (TEU),

the Union shall act only if and in so far as the objectives of the proposed action cannot be sufficiently achieved by the Member States, either at central level or at regional and local level, but can rather, by reason of the scale or effects of the proposed action, be better achieved at Union level.

The quota on women is a current example of a conflict of jurisdiction between European and national legislation. ${ }^{130}$ The European Commission justifies the compatibility of the Draft Quota on Women Directive with the principle of subsidiarity by stating that some member states would not be willing to introduce quotas on women, and secondly by stating that the absence of statutory quotas in some member states and the sometimes different organisation of existing quotas would have a negative impact on the European Single Market. ${ }^{131}$ However, the various regulations already in existence and the new law in Germany show that gender quotas can be implemented on a national level. ${ }^{132}$ Furthermore, the argument of a risk to the European Single Market seems to be exaggerated. It must also be noted that a 'European quota on women' may conflict with national constitutional law, ${ }^{133}$ and may ultimately affect the different structures of supervisory boards in the individual

\footnotetext{
128 Thüsing, above n 60, 372.

129 See also Marco Buschmann, 'EU-Grünbuch zur Corporate Governance: Alter Wein in neuen Schläuchen?’ (2011) 14 Neue Zeitschrift für Gesellschaftsrecht 87, 90; Möllers and Hailer, above n 3, 850 with further references.

130 Similarly Möllers and Hailer, above n 3, 850.

${ }^{131}$ EC Draft Directive 2012, above n 12, 10-11.

132 Buschmann, above n 129, 90.

133 Institut für Gesellschaftsrecht der Universität zu Köln, 'Stellungnahme zum Grünbuch der EU-Kommission vom 5. 4. 2011: Europäischer Corporate Governance-Rahmen’ (2011) 14 Neue Zeitschrift für Gesellschaftsrecht 975, 977.
} 
countries. ${ }^{134}$ Therefore, to uphold the principle of subsidiarity, blanket European regulations should be rejected. ${ }^{135}$

Finally, the fact that companies in the legal form of a SE also fall under the quota regulation might result in a possible conflict with European law. ${ }^{136}$ The German Ministry of Justice has always preferred the inclusion of the SE in the scope of application of the quota on women. Otherwise there might have been the risk of companies being able to circumvent the quota by changing their legal form. ${ }^{137}$ However, in the draft bill of June 2014 no strict quota was imposed on such companies: they 'should' only fulfil the 30 per cent quota. ${ }^{138}$ This means that they were exempt from the requirement of a fixed quota. Therefore it is quite surprising that the German legislator has now returned to the original plans of the Ministry of Justice.

\section{SUMMARY AND OUTLOOK}

The issue of quotas on female membership of corporate boards has been a topic on the Continent for a long time, and has now again become a focal point of company law due to the legislative actions of Germany and the EU. The political decision to impose quotas has already been made. Nevertheless, current procedures must still be followed critically, and alternative proposals must still be made. Due to the disputed constitutionality of the quotas in Germany, the last word on the specific structure of a legal quota on women has still not been spoken. Irrespective of the constitutional law dimension, the legislator should have introduced strict gender quotas only as a last resort. A solution in terms of flexi-quotas should have been sought instead. Flexi-quotas are a balance between strict quotas in the sense of state compulsion and nonbinding recommendations from the Corporate Governance Code. They largely protect corporate co-determination, whilst at the same time taking the state's

\footnotetext{
134 A distinction is made here between dualistic and monistic company organisation: see Teichmann and Langes, above n 27, 177.

135 Also Buschmann, above n 129, 90; Institut für Gesellschaftsrecht der Universität zu Köln, above n 133, 977; BT-Drucksache 17/6506, 4 (Parliamentary Documentation of the German Bundestag) <http://dipbt.bundestag.de/dip21/btd/17/065/1706506.pdf > .

${ }^{136}$ Barbara Mayer, ‘Gesetzentwurf zur Frauenquote mit einigen Überraschungen’ (12 August 2014) Friedrich Graf von Westfalen and Partners Lawyers <http://www.fgvw.de/2367-0Gesetzentwurf+zur+Frauenquote+mit+einigen+Ueberraschungen.html>.

${ }^{137}$ Karl-Heinz Büschemann, ‘Ganz andere rechtliche Fragen’ Süddeutsche Zeitung, 9 May 2014, 19.

${ }^{138}$ SEAG-E $\S 17$ para 2 and SEBG-E § 21 para 5 as in the Draft Act for the Equal Participation of Men and Women in Management Positions in Private Industry and Public Services, above $\mathrm{n}$ 35.
} 
duty to realise gender equality into account (article 3 paragraph 2 clause $2 G G$ ). At European level, the topic of quotas on women should be dealt with carefully. For reasons of subsidiarity, responsibility should remain with national states.

It remains to be seen whether quotas on women can fulfil the expectations held of them. It can certainly be expected that the introduction of a quota will increase the proportion of women on supervisory boards. Additionally, with female supervisory board members, a new, independent professional profile could be established for the future, which would not least promote the professionalisation of supervisory boards. ${ }^{139}$ It is uncertain whether quotas on women will improve the professional promotion of women on supervisory boards, as can be seen from looking at developments in Norway. A recent study there found that, despite the introduction of a quota on women in 2003, the proportion of women in middle management positions has remained unchanged, and has only increased on the highest management level. The wage gap between men and women has not changed significantly either; in other words, the quota on women has not yet led to an integral change in working conditions for women. ${ }^{140}$ These experiences show that the topic of female advancement must be approached from many sides. Solely limiting this to an increase in the proportion of women on supervisory boards is not sufficient. The fact that in Germany now targets for management positions below the supervisory and the executive board must also be set, is therefore a step into the right direction. Nevertheless, changes must be made on other levels as well. ${ }^{141}$ Today, the question of whether women pursue a professional career increasingly depends on the compatibility between family and a career. ${ }^{142}$ This can be seen in Sweden and Denmark, where - as previously discussed - there are still no statutory quotas. In spite of this, the proportion of women on supervisory boards is well over 20 per cent there. ${ }^{143}$ It is true that female advancement is on the political agenda. However, it is questionable whether company law should be used as an important vehicle to achieve it. On the one hand, quotas on women are a foreign body in company law; on the other hand,

\footnotetext{
139 Bachmann, above n 3, 189.

${ }^{140}$ Lin Freitag, 'Wird Norwegen vom Vorbild zum Versager?', Die Zeit (online), 13 August 2014 $<$ http://www.zeit.de/karriere/2014-08/frauenquote-fuehrungskraft-unternehmen-norwegen>.

${ }^{141}$ Similarly Redenius-Hövermann, above n 88, 666.

142 Hirte, above n 14, 368f, 379.

143 Teichmann and Langes, above n 27, 179.
} 
they are insufficient. For professional advancement, there must be, if nothing else, comprehensive family-related political reforms and improvements regardless of gender! ${ }^{144}$

144 Bachmann, above n 3, 189; see also Peltzer, above n 20, 283; Thüsing, above n 14, 16; concerning the different options see Hirte, above n 14, 379. 